\title{
Hybrid observer for high cell density cultures exhibiting overflow metabolism
}

\author{
Lisbel Barzaga Martell ${ }^{1}$, Manuel Duarte-Mermoud ${ }^{1}$, Francisco Ibañez Espinel ${ }^{2}$, Bastian \\ Gamboa Labbé1, and José Pérez-Correa ${ }^{2}$ \\ ${ }^{1}$ University of Chile \\ ${ }^{2}$ Pontificia Universidad Catolica de Chile
}

October 20, 2020

\begin{abstract}
This work proposes a hybrid observer based on an asymptotic observer and an extended Kalman filter applied to S. cerevisiae's high-density cultures. The observer estimates biomass and ethanol concentrations based on dissolved oxygen, carbon dioxide, and substrate measurements. Numerical simulations show that the proposed hybrid observer is useful for monitoring the respirative and the respiro-fermentative regimes in high cell density cultivations, showing a robust behavior against measurement noise. The Monte Carlo simulations allowed the evaluation of the observer's performance when faced with changes in the plant's parameters, showing stability in all the evaluated scenarios. The methodology used in this study can be extended to different cell factories such as Pichia pastoris and Escherichia coli, modifying the yields and the kinetic and equilibrium parameters.
\end{abstract}

\section{Hosted file}

BTJ-template-RA-2020 - Lisbel (v5).pdf available at https://authorea.com/users/368935/ articles/487938-hybrid-observer-for-high-cell-density-cultures-exhibiting-overflowmetabolism

\section{Hosted file}

Figure 1.rar available at https://authorea.com/users/368935/articles/487938-hybrid-observerfor-high-cell-density-cultures-exhibiting-overflow-metabolism

\section{Hosted file}

Figure 2.rar available at https://authorea.com/users/368935/articles/487938-hybrid-observerfor-high-cell-density-cultures-exhibiting-overflow-metabolism

\section{Hosted file}

Figure 3.rar available at https://authorea.com/users/368935/articles/487938-hybrid-observerfor-high-cell-density-cultures-exhibiting-overflow-metabolism 